\title{
WATER SECURITY IN CENTRAL ASIA AND SOUTHERN CAUCASUS
}

\author{
Zulfiya Suleimenova*
}

The dissolution of the Soviet Union, and the emergence of new States in Central Asia and Southern Caucasus has created new political and security dynamics in these regions. The latter was affected by the NagornoKarabakh conflict and the former is confronted by the threat of conflict over shared water resources. More than twenty years later, the protracted conflict in Southern Caucasus over Nagorno-Karabakh remains unresolved and overshadows water-related problems; despite this, the dispute over water is a very important factor in the conflict, and key to overcoming it. In Central Asia, although the threat of conflict over water resources did not materialize, the region remains under the spotlight of water-conflict literature. In the present paper, the complex nature of water security is reviewed through an in-depth analysis of security and development-related factors in their connection to water and vice versa, which leads to the conclusion that policy interventions should be based on a more holistic approach that includes a wider set of issues.

JEL classification: F51, Q25, Q34

Keywords: water conflict, water cooperation, water security

Zulfiya Suleimenova, PhD Candidate, Security and International Studies Program, National Graduate Institute for Policy Studies (GRIPS), Tokyo, Japan (email: belgisiz.zhan@gmail.com). This paper does not imply the expression of any opinion whatsoever on the part of the Secretariat of the United Nations concerning the legal status of any country, territory city or area or its authorities, or concerning the delimitations of its frontiers or boundaries. 


\section{INTRODUCTION}

Water has always been central in human history: it was integral to many cultures and religions, and key to the advancement of many civilizations. Despite this, water has been underappreciated until recently.

Environmental degradation, overexploitation, the looming climate crisis and the consequent deterioration of water resources had prompted the rethinking of water's role in the global political agenda. For example, the United States Intelligence Community conducted an assessment on global water security in 2012. Based on the assessment, it warned that by 2040 , global demand for water will outstrip supply by 40 per cent and that the supply problem combined with poverty, environmental degradation and weak political institutions, will result in State failure and increased tensions over water resources. In the report, it was stated that "as water shortages become more acute beyond the next 10 years, water in shared basins will increasingly be used as leverage; the use of water as a weapon or to further terrorist objectives also will become more likely beyond 10 years" (Intelligence Community Assessment, 2012 , p. iii). Accordingly, the concept of "water security" has emerged as an attractive paradigm to deal with the role that water may play in the wider political and development agenda.

To date, many watercourses are shared among two or more countries, which elevates the importance of transboundary water cooperation to ensure water security in its wider definition and achieve sustainable development. Many scholars have elaborated methodological frameworks to understand water cooperation dynamics or the lack thereof in shared basins (Zeitoun and Mirumachi, 2008; Zeitoun, Mirumachi, and Warner, 2011; Mirumachi, 2010; Warner and Zawahri, 2012; Delli Priscolli and Wolf, 2009; Allouche, 2005). This literature aids efforts aimed at understanding the water-security nexus, with development as an intervening factor and the waterdevelopment nexus with security as an intervening factor. Respectively, water is seen as central to socioeconomic development of States and achieving sustainable development. But, the link between water and conflict is not straightforward: "it is impossible to develop a catalogue of all factors potentially intervening along the causal chain between water and conflict" (Schmeier and others, 2018, p. 3). Recently, much effort has focused on developing the tools that make it possible to identify water conflicts before their onset, which are often linked to developmental objectives.

The contribution of the present paper is that it digs into the complex causal nature of regional water security or security in general in two regions - Central Asia and Southern Caucasus. By doing so, it can be ascertained that security in these two regions is intrinsically linked to water, but there needs to be much more comprehensive analysis of causal factors, not just "snapshot" views, to see the big picture. The first 
part of this paper includes a discussion on how water security is defined and its link with development literature, then an in-depth analysis of two cases and a discussion is provided, followed by a conclusion and policy recommendations.

\section{WATER IN SECURITY AND DEVELOPMENT LITERATURE}

In 1983, Richard Ullman, in his work on redefining security, argued that "defining national security merely (or even primarily) in military terms conveys a profoundly false image of reality," and suggested that security should be defined as "an action or sequence of events that... threatens drastically and over a relatively brief span of time to degrade the quality of life for the inhabitants of a state..." (UIIman, 1983, pp.129, 133). In 1987, the Brundtland Commission report entitled "Our common future: report of the World Commission on Environment and Development" stressed the need to expand the traditional notion of security to include "growing impacts of environmental stress - locally, nationally, regionally, and globally" (Bruntland Commission, 1987, p. 24).

The expansion of the security definition to include the environmental vulnerabilities and factors has led to increased attention to water security as a concept to explain various aspects of water-related issues. It should be noted, however, that although the use of the term has increased and is being used in a wide range of disciplines, the approaches and scales have varied greatly. As such, in the 1990s, water security was mainly used with regard to water wars (Wolf, 1997) and water terrorism (Gleick, 2006). Later, the definition was expanded to include the access to and affordability of water resources and its human security dimension (Cook and Bakker, 2012).

UN-Water (2013, p. vi) defines water security as "the capacity of a population to safeguard sustainable access to adequate quantities of acceptable quality water for sustaining livelihoods, human well-being, and socioeconomic development, for ensuring protection against water-borne pollution and water-related disasters, and for preserving ecosystems in a climate of peace and political stability". Wegerich and others (2015, p. 4659), however, emphasize that although this definition focuses on the demand side of water security, it "critically lacks reference to the supply-side".

On the other hand, water security in most literature is considered through the environmental security lens and linked to food or human security. Libiszewski (1992), however, argues that environmental conflicts are not necessarily the struggle for scarce natural resources, but they can be manifested as conflicts induced by degradation of natural resources. In this respect, there is need to distinguish between environmental and geopolitical scarcity in which the former is directly linked to scarcity as a result of environmental degradation and the latter stems from uneven distribution of 
natural resources. Accordingly, distinguishing between the two is important to better understand the conflict dynamics over natural resources.

With the growing salience of the development paradigm, there is also need to effectively draw linkages between development and water security concepts. Development, by definition, is generally about change, "not just any change, but a definitive improvement" (Slim, 1995, p. 143). In this respect, water security in a wider definition should embed the considerations of both the demand and supply-sides of water, as well as its human security aspect and be linked to the overall betterment in society and countries of concern.

Such betterment requires effective cooperation in the transboundary context in which shared watercourses are central for socioeconomic development and the environmental sustainability of adjacent territories. As such, shifts in political divisions associated with the integration or disintegration of political units that result in changes in riparian relations may be an indicator of potential water conflict in the transboundary basins (O'Hara, 2000) because of changing historical patterns of appropriation and utilization of water resources caused by new political borders (Weinthal, 2002). The alteration of interests of new nation-States and the asymmetries in relative capabilities are viewed as common causes of water conflicts.

Accordingly, the politico-military dimension of water security should be based on establishing cooperative arrangements that facilitate dealing effectively with arising challenges. Given that "the mere existence of cooperative arrangements is often celebrated as a sign of progress, with little or no interrogation of their influence over the intended goals of the cooperation" (Kistin and Phillips, 2008), it is imperative that water security at the transboundary level takes into account cooperation that is equal in terms and acceptable by all participating countries.

\section{WATER SECURITY IN CENTRAL ASIA}

The water resources of Central Asia are comprised of two major endorheic rivers, the Syr Darya and the Amu Darya, which originate from the snowy peaks of the Tian Shan and Pamir mountains, flow crossing the borders of seven countries (Afghanistan, the Islamic Republic of Iran, Kazakhstan, Kyrgyzstan, Tajikistan, Turkmenistan and Uzbekistan), and terminate in the Aral Sea. The Amu Darya river's flow is formed mainly in Tajikistan (about 80 per cent), Afghanistan (12 per cent), Uzbekistan (6 per cent), and Turkmenistan (3.5 per cent). In the Syr Darya river basin, Kyrgyzstan contributes about 74.2 per cent of the river flow, followed by Kazakhstan, 12.1 per cent, Uzbekistan, 11.1 per cent, and Tajikistan, 1.1 per cent (Ibatullin, 2013). Melting glaciers of snow peaked mountains are a major source of nourishment. 
The arid climate of the region with low and irregular rainfalls had necessitated the development of irrigated agriculture from old times. Agricultural development was also strongly linked to historical processes that took place in the region. The expansion of the Russian Empire to Central Asia was not initially driven by the need for large-scale cotton production (Obertreis, 2017); it became a priority after growth in demand for cotton from domestic textile producers following the 1861 Emancipation Reform and an increase in world prices resulting from the decline in cotton from the United States of America as the result of the American Civil War. During the Soviet period (1918-1991), the policy of economic orientation transformed Central Asia into the cotton basket of the Soviet Union, with Uzbekistan becoming one of the world's leading cotton producers.

\section{Figure 1. Water Resources in Central Asia}

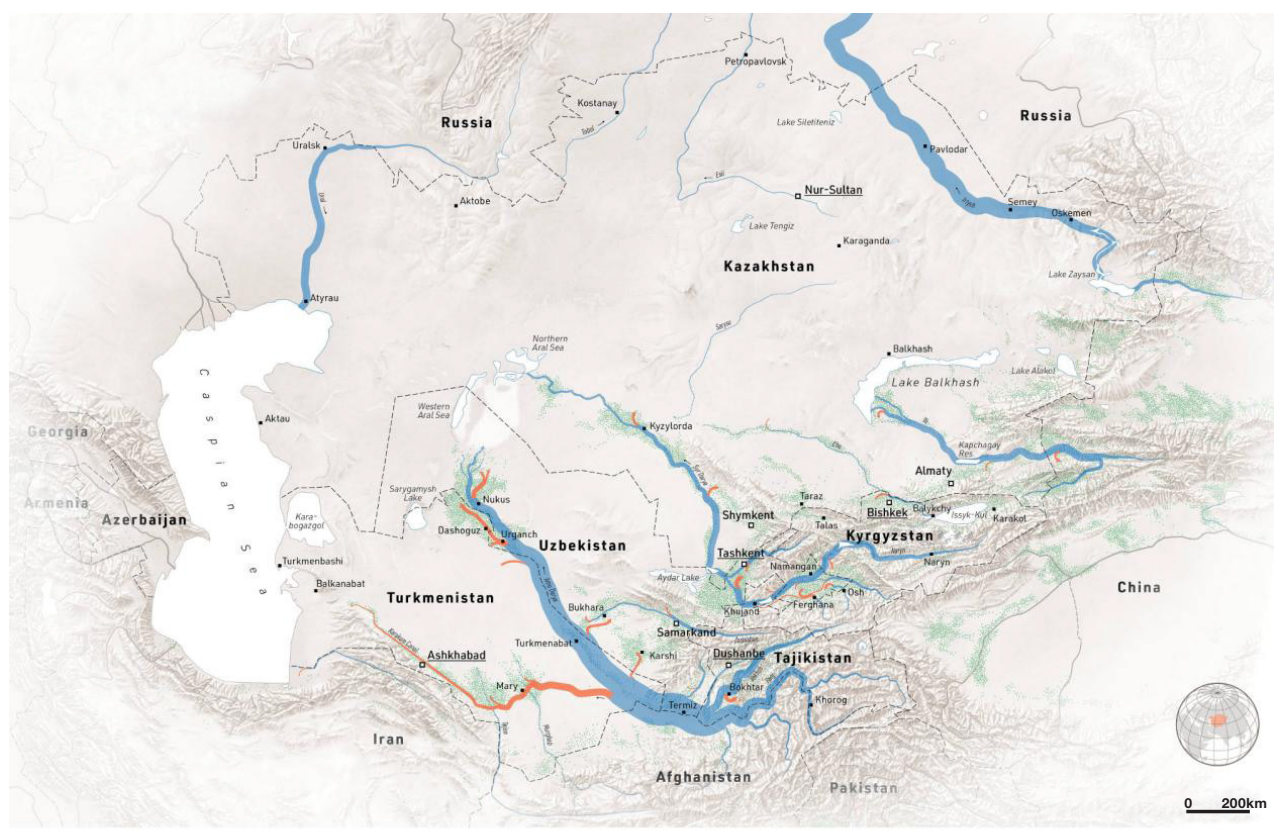

Source: World Bank (2019).

Note: The boundaries and names shown and the designations used on this map do not imply official endorsement or acceptance by the United Nations.

During the Soviet period, water was managed based on water-energy swap logic in which upstream States run their hydropower facilities in irrigation mode, prioritizing the water release during the vegetation season for the needs of downstream irrigated 
agriculture. Energy shortages during the winter in those countries were compensated by fossil fuel deliveries from downstream countries and the Unified Energy System of Central Asia, a power grip system set up in the 1980s.

After independence, countries initially agreed to continue with the established water management scheme. An agreement signed in February 1992 by Kazakhstan, Kyrgyzstan, Tajikistan, Turkmenistan and Uzbekistan, referred to as the Almaty Agreement, provided that the Parties shall have equal rights to water use and responsibility to ensure rational use and protection of water. ${ }^{1}$ Countries reconfirmed the previous arrangements based on water quotas and a water-energy barter mechanism.

The Almaty Agreement and the following legal acts were referred to regulating cooperation on environmental issues and to establishing a joint institutional framework, which, however, failed to prevent the rise of grievances among countries over the shared water resources. In August 1993, the Interstate Commission for Water Coordination, an institutional framework established to regulate the regional cooperation efforts, blamed Kyrgyzstan of "unilateral change of regime of the Syr Darya rivers... in the interests of its energy sector..." (Central Asian Research Institute for Irrigation, 1993, p. 14). This rather stemmed from the problems that remained unaddressed by new agreements hastily made in the early 1990 s.

These developments led to speculation that "nowhere in the world is the potential for conflict over the use of natural resources as strong as in Central Asia" (Smith, 1995, p. 351). The Pacific Institute, based on its water conflict database, also indicated that in the period 1990-2014, at least 13 conflicts over water resources in Central Asia were recorded, including development disputes, water used as either a political or military tool or target, or in an attempt of a terrorist act. Four of them were classified as violent, while the rest were considered to be non-violent (Gleick and Heberger, 2014). The Water Cooperation Quotient of the Strategic Foresight Group, on the other hand, has put four out of five Central Asian States under the risk of war over water resources (Philip and others, 2015).

This leads to question why there reportedly has been conflict potential in the region even though water cooperation agreements were signed, and an institutional framework was established and also what kind of implication these dynamics have on the region's development prospects.

See "Agreement between the Republic of Kazakhstan, the Kyrgyz Republic, the Republic of Tajikistan, Turkmenistan and the Republic of Uzbekistan on Cooperation in the Field of Joint Management on Utilization and Protection of Water Resources from Interstate Sources". Available at www.icwc-aral. uz/statute1.htm. 
The energy and irrigation systems in Central Asia were among the most complex ones; hence, they required a high level of coordination. Often the Soviet rule in the region was seen as being based on "divide and rule", in which "disputes over water reinforced the national distinctiveness of the republics, thus limiting the potential for regional political cooperation, which would threaten Soviet control" and "as competition for water increased, the republics had little choice but to ask Moscow to intervene, a role Moscow willingly undertook" (O'Hara, 2000, p. 378).

On the other hand, the water-energy infrastructure was built disregarding the borders of administrative units (or treating them as a mere formality), making the system highly connected and the republics interdependent from one another. Some have argued in this regard that the Soviet rule was based on the "integrate and rule" principle instead (Wegerich, 2008, p. 85). As such, the dissipation of central administration, and fragmentation of water and energy management and planning left States unable to ensure the required level of coordination, threatening the operation of the old management system. Micklin $(2000$, p. 3) respectively suggested that the lack of power "to dictate water management policy in the region" was among the factors that contributed to heightened tensions among States.

At the same time, while the Soviet water management system was preserved, other regional approaches that supported it, such as food and energy exchanges, disappeared (Wegerich, 2004). New policy priorities arose in the post-1991 period, and the countries proceeded with national food and energy security policies, which sometimes clashed with the interests of other States, especially along upstream and downstream lines. For example, the privatization of State and collective farms in upstream Kyrgyzstan in the early 1990s resulted in the growth of private farms that changed the agricultural practices from livestock to cash crops, and consequently led to greater demand for water (Wegerich, 2004). The small changes at the country level had impacts on the water use and allocation at the transboundary level.

Looking at the nature of conflict in the two river basins of interest, one can distinguish similar yet different dynamics and causes. In general, three conflict points can be defined: water as a commodity; infrastructure building; and conflict between hydropower and irrigation regimes of water facilities.

The first conflict point has evolved around water being treated as a commodity that should be paid for. This approach emerged as a result of the pitfalls of the established water management system, which favoured downstream irrigation. The arrangements considered that the upstream States were to store water in winter to release it during vegetation season. The emanating hydropower was purchased by the downstream States. The energy deficit during winter was covered by coal, oil and gas deliveries from downstream to upstream States. 
Shortly after independence, the downstream countries of Kazakhstan and Uzbekistan set market prices on their fuel, ${ }^{2}$ forcing upstream countries to shift to a hydropower generation regime, which meant that water was released in winter to generate more electricity. This intensified the conflict as the operation of the hydropower facilities led to a water deficit during the vegetation season and floods in the non-vegetation season. In 1997, the Upper House of the People's Representatives of Kyrgyzstan passed a resolution in which water was recognized as a commodity, and in 2001, water was reiterated as a state property under the Law on Interstate Use of Water, which should be paid for by other States. In response, Uzbekistan cut deliveries of natural gas to Kyrgyzstan and accused it of failing to follow existing agreements.

The failure of the newly established water regime to arrest the growing disagreements among States can be attributed to the very nature of the agreement. Despite the widespread belief that "once cooperative water regimes are established through treaties, they turn out to be impressively resilient over time, even between otherwise hostile riparians, and even as conflict is waged over other issues" (Wolf, Yoffe and Giordano, 2003, p. 2). It is important to note that if components of a treaty are not implemented or are unequal in terms, favouring interests of one actor over a collective will result in "poor cooperation" or even "non-cooperation" (Zeitoun and Mirumachi, 2008, p. 303).

The reconfirmed water management system in Central Asia reflected the Soviet legacy, which was based on unequal water distribution aimed at enhancing irrigation productivity in the region (Wegerich, 2004), and failed to consider economic interests and the needs of Soviet Central Asian republics. The system did not respond to political interests and economic priorities of newly emerged countries either. For example, while it was agreed that water should be used in the same manner as during the Soviet period, the costs of operation and maintenance of infrastructure were inflicted on upstream States (Wegerich, 2004). On the other hand, while the focus was on water allocation, no real mechanism for dealing with disputes was developed.

The second conflict point evolved around building new infrastructure and was inherent to both river basins. In the Syr Darya, the plans of Kyrgyzstan to complete the

\footnotetext{
Although both countries are well endowed with energy resources, in the early 1990s, they faced challenges in providing energy to upstream States at the subsidized rates previously applied. The Soviet economic orientation policy resulted in high dependence of States on the goods that they did not produce. Uzbekistan had unrealized energy producing potential, which made it a net energy importer. It faced world market prices for wheat and energy products, while also running a trade deficit in energy and consumption goods. For Kazakhstan, one of the key challenges was the connectivity between regions. Respectively, although the country had rich oil and coal reserves, these commodities were mainly concentrated in the western and northern provinces of Kazakhstan. The southern provinces were dependent on power imports from neighbouring Central Asian States.
} 
construction of the Kambar-Ata I reservoir to meet the winter peak of domestic energy demand was opposed by downstream Uzbekistan, which feared the sustainability of water supplies. The conflict here is not as profound, partly because of lack of clarity regarding investments.

The conflict in the Amu Darya basin, on the other hand, was about transboundary resource abstraction. Tajikistan, which generates up to 80 per cent of the river's water resources, but is not well endowed with fossil fuels, wanted to construct the world's tallest hydropower plant on the Amu Darya tributary - the Vakhsh River - to achieve energy security. The project was planned in 1976, but was stopped in the 1990s. After independence, Tajikistan attempted to attract external investments to complete construction, however, disagreements and strong opposition from the lower riparian States effectively blocked financing for the project. The Government of Tajikistan argued that construction would allow better regulation of the river flow, which would equally benefit downstream States' irrigation needs. Studies suggest, however, that "Rogun ${ }^{3}$ does not play a significant role in helping enhance summer flows for use in downstream irrigation" (Bekchanov and others, 2015, p. 869). The construction of the dam would result in a significant increase in hydropower production with relatively minor adverse impacts on downstream irrigation if it is implemented through a "cooperative optimal basin-wide management" (p. 869). However, if the benefits from hydropower generation are unilaterally maximized, it will only marginally improve energy production benefits, while significantly affecting the downstream agricultural sector (Bekchanov and others, 2015).

In the past few years, the situation is believed to have greatly been altered to a more positive direction. Uzbekistan, which opposed the hydraulic projects in upstream States, has begun to change its policy in support of such projects, and has even expressed interest in participating in them. It is, however, too early to judge about the outcome of Uzbek initiatives and see the extent at which the old policies have been altered. On the other hand, it is unlikely that upstream countries would really allow the participation of downstream riparians in their strategic projects. Essentially, the issue is not only about having those facilities, but also exercising effective control over their operation.

The last but not least point of conflict to look at is the one between hydropower operation and irrigation modes of hydraulic facilities of the region. The earlier described conflict points are connected to the water for irrigation and water for hydropower dilemma. Lack of an effective mechanism that addresses the interdependencies and diverse needs and interests of States results in a zero-sum situation around the

The name of the hydropower dam. 
operation of hydraulic facilities. As an example, there is an inherent fear among the downstream States that the facilities might potentially be used as tools to maximize power. As such, plans to build the Rogun Dam on the Vakhsh River were perceived as an aspiration of Tajikistan to gain more control over water resources, and thus win more power over downstream riparian States.

The latter point can also be traced to the nation- and State-building needs beginning in the early 1990 s. According to Allouche (2005, p. 108), the emergence of nation-States translates into the need of State-building that can be understood as a State's "capacity to monitor, circumscribe and control resources and people within its territory." In this respect, water is considered as an indispensable element of a State's ability to exercise control over its territory. In Central Asia, after the elimination of the authority of Moscow, the nation-building problems became more salient; water became an issue of national concern, whereas the control over territory was equalized to direct control over natural resources, including water (Allouche, 2005). This can be seen from States' national legislation as well. For example, in the Water Code of Kazakhstan, it is stated that "the water fund of the Republic of Kazakhstan is an exclusive state property"4; and the Law of the Republic of Uzbekistan on Water and Water Use stipulates that "water is the State ownership - the national wealth of Uzbekistan - and is subject to rational use and government protection."

\section{WATER SECURITY IN SOUTHERN CAUSACUS}

In Southern Caucasus, ${ }^{6}$ the rivers of Kura and Araks are the main water arteries. Approximately 65 per cent of the basin is in the countries of Southern Caucasus, while the rest is shared between the Islamic Republic of Iran (19.5 per cent) and Turkey (15.1 per cent). The key tributaries of the Kura River are the Mtkvari and the Postkhovi, originating from Turkey, and the Debet and the Agstay, from Armenia. The Araks River originates in Turkey, but continues as a border between Armenia and Turkey, Azerbaijan and Turkey, Armenia and the Islamic Republic of Iran, and Azerbaijan. Water distribution is uneven, with Georgia being the most water-abundant country, and Azerbaijan being the most water scarce. Seventy per cent of the water sources in Azerbaijan come from outside the country.

4 See The Water Code of the Republic of Kazakhstan No.481, 9 July 2003.Available at http://adilet. zan.kz/eng/docs/K030000481_.

5 See Law of the Republic of Uzbekistan on Water and Water Use. Available at www.fao.org/faolex/ results/details/en/c/LEX-FAOC005255/.

6 For this paper, Azerbaijan, Armenia and Georgia comprise the Southern Caucasus region. 


\section{Figure 2. Water Resources in Southern Caucasus}

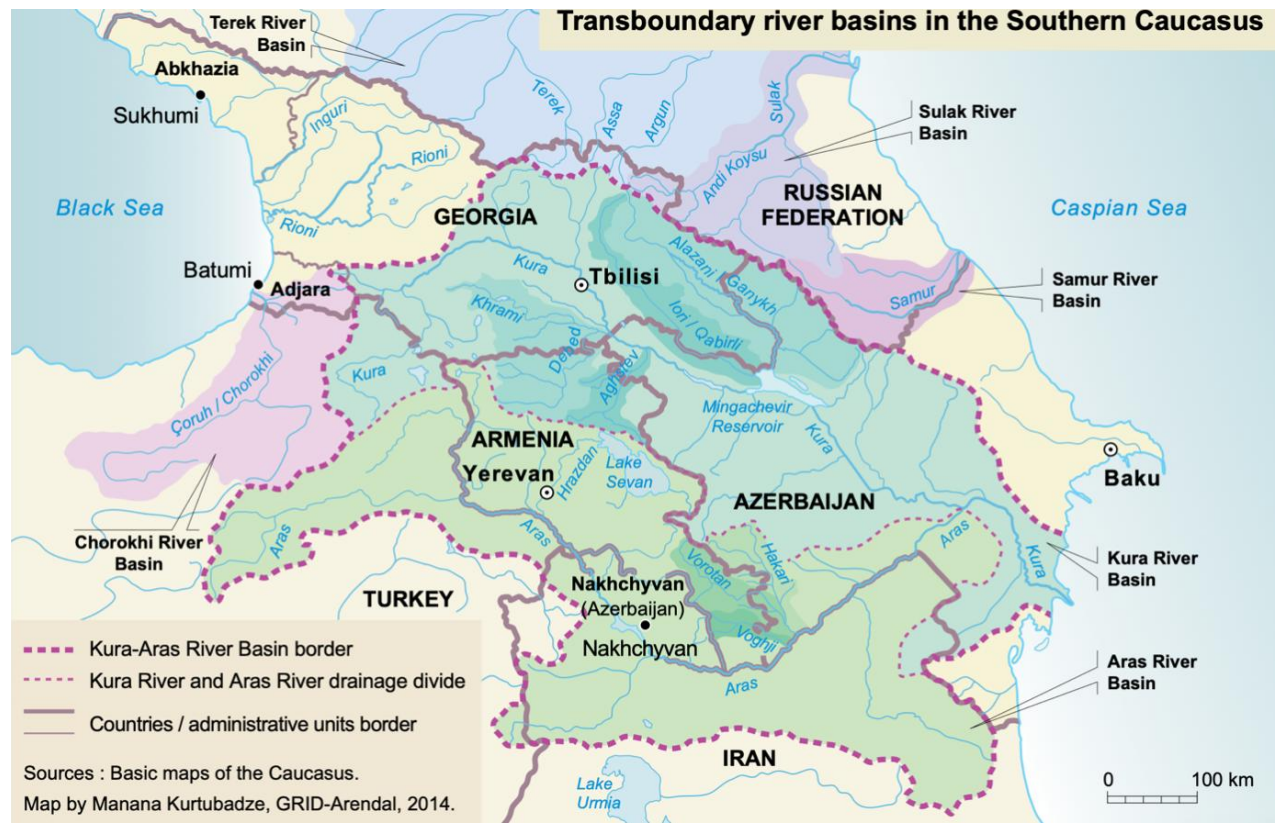

Source: Rucevska (2017).

Note: The boundaries and names shown and the designations used on this map do not imply official endorsement or acceptance by the United Nations.

Most of the literature on Southern Caucasus focuses primarily on the conflict between Armenia and Azerbaijan over the Nagorno-Karabakh ${ }^{7}$ as an ethnic and territorial confrontation between the two countries. However, water is one of the cross-cutting factors linked to peace and stability in the region, which is often overshadowed by the above territorial dispute.

The Nagorno-Karabakh conflict is between Armenia and Azerbaijan over the Nagorno-Karabakh region and surrounding districts. During the Soviet period, the Nagorno-Karabakh had autonomous status under Azerbaijan Soviet Socialistic Republic. It had a mixed population consisting of Armenians, who lived predominately in the hills and the Azerbaijanis, who were concentrated in the plains. Although the mountainous part of Karabakh was given to Azerbaijan as per a decision of Kavburo (the Bolshevik Caucasian Committee), the decision was never fully accepted and led to protests in 1945, 1965, and 1977. After the breakup of the Soviet Union, the wish of Nagorno-Karabakh Autonomous Oblast to secede from Azerbaijan and union with Armenia resulted in a conflict between the latter two that began in 1991 and ended in 1994, resulting in the death of thousands of people and the displacement of more than 500,000 people. In 1994, the ceasefire was signed and the Organization for Security and Co-operation in Europe Minsk Group was established to mediate the conflict. The efforts have reportedly failed, and the talks were frozen. For more information, see De Waal (2005) and Organization for Security and Co-operation in Europe (2009). 
Similar to Central Asia, the breakup of the Soviet Union transformed the Soviet portion of the Kura-Araks basin into a transboundary, shared by three States Armenia, Azerbaijan and Georgia. The basin, which feeds the region's agriculture (fruits and grapes in the mountainous areas of upstream States, and cotton in the downstream State of Azerbaijan), is a lifeline for the three States for sustaining their socioeconomic development. To date, one of the pressing problems is the pollution of the basin and lack of adequate cooperation stemming from ongoing political conflict between Armenia and Azerbaijan. Although good cooperation exists at the bilateral level, to ensure good management of shared watercourses, the establishment of an efficient multilateral water management scheme with participation of all countries concerned, including those not regarded as Southern Caucasus, is required. ${ }^{8}$

Water cooperation in the Kura-Araks basin and the Nagorno-Karabakh conflict are mutually connected. The Transboundary Freshwater Dispute Database, established by Oregon State University, has shown that most water-related conflict events that took place in the basin between 1991 and 2003, especially between Armenia and Azerbaijan, were related to the Nagorno-Karabakh conflict. ${ }^{9}$ The intensity of these interactions varied from "small-scale military acts" as the most intense to "minor official exchanges" as the most positive event during the given period, meaning that such conflictual pattern results in minimal interaction regarding the establishment of a multilateral water management mechanism. ${ }^{10}$ Accordingly, it can be concluded that resolution of water-related issues in the region is closely linked to resolution of the Nagorno-Karabakh conflict.

It should be pointed out that the water factor is often overlooked in the above conflict, but its role is twofold: on the one hand, it underpins the water and energy security of Nagorno-Karabakh and partially of Armenia, while on the other hand, it is critical for the development, security and safety of the neighbouring regions of Azerbaijan.

Discussions on the conflict usually unfold around the strategic importance of Nagorno-Karabakh with regard to military security, transportation network, and economic viability (Dietzen, 2014). This area has, however, another strategic role, namely water security.

8 The Kura-Araks river basin is shared by Armenia, Azerbaijan, Georgia, the Islamic Republic of Iran and Turkey.

9 See Transboundary Freshwater Dispute Database. Available at http://gis.nacse.org/tfdd/ internationalEvents.php. For more details also review Wolf (1999).

10 The Transboundary Freshwater Dispute Database was developed as part of the Basins at Risk project. It documents the historical water relations in transboundary water basins worldwide. To better reflect the level of event intensity in the basin, the Water Event Intensity Scale has been developed. For more information, see Yoffe and Larson (2001). 
The lion's share of water that flows into the area is formed in Kalbajar. The district provides about 60 per cent of the water that flows into Karabakh. It also sustains the Vorotan River, which, in turn, helps to replenish Lake Sevan in Armenia. Lake Sevan sources about 80 per cent of the water resources of Armenia (Dietzen, 2014).

The two regions of the former Nagorno-Karabakh is also home to the widely discussed and contested Sarsang Dam. The dam, which was built in the 1970s on the Tartar River, provides 40 to 60 per cent of Karabakh electricity. It has a capacity of 560 million cubic meters $\left(\mathrm{m}^{3}\right)$, and is at about 700 meters above the sea level (Rzayev, 2015). According to Azerbaijani officials and experts, the risk associated with the Sarsang Dam may be the result of obsolescence of hydraulic facilities and equipment, and growth in intensity of calamities worldwide, which may have an impact on the disasters in the Caucasus.

In 2015, upon the request of Azerbaijan, the issue pertaining to the physical condition of the Sarsang Dam was brought to the Parliamentary Assembly of the Council of Europe. The Assembly's rapporteur at the time emphasized that the lack of regular maintenance of the dam is threatening the entire area, and asserted that "the inhabitants of bordering regions of Azerbaijan are deliberately deprived of water". In January 2016, the Assemby passed a resolution in which it considered that "the deliberate creation of an artificial environmental crisis must be regarded as 'environmental aggression' and seen as a hostile act by one State towards another..." and while noting that "the lack of regular maintenance work for over twenty years on the Sarsang reservoir, located in one of the areas of Azerbaijan occupied by Armenia, poses a danger to the whole border region," requested "the Armenian authorities to cease using water resources as tools of political influence or an instrument of pressure benefiting only one of the parties to the conflict." "11 The resolution was adopted by 71 votes with 42 against and 49 abstaining. Commenting on the resolution, an Armenian official declared that the adoption of such resolution undermines the efforts aimed at resolving the Nagorno-Karabakh conflict (NEWS am, 2015).

The Sarsang Dam represents a security dilemma, as it can potentially be used as political leverage or a military tool because of its strategic location and the impact it may cause. Some Azerbaijani officials indeed claimed that there was a risk of dam destruction for military purposes during the first days of the Nagorno-Karabakh conflict in the early 1990s. Accordingly, the insecurities are deeply engrained in this dispute with Azerbaijan, framing this status quo as "hydro-terror" against their country (Rzayev, 2015).

\footnotetext{
See Parliamentary Assembly of the Council of Europe Resolution 2085: Inhabitants of frontier regions of Azerbaijan are deliberately deprived of water (2016). Available at http://assembly.coe.int/nw/xml/ XRef/Xref-XML2HTML-EN.asp?fileid=22429\&lang=en.
} 
At the same time, although water plays a large role in security dynamics of the region, "it is not likely to trigger large-scale violence," but rather "increase the existing tensions over resources with catalytic and far-reaching effects for the region" (Ivanova, 2009). Accordingly, failure to recognize its strategic role in the security of Armenia and unrecognized Nagorno-Karabakh would certainly put the peace talks into a deadlock. Recognizing and addressing the complexity of the water-security nexus in the region would help in tailoring the solutions and confidence-building measures required to attain peace.

\section{v. DISCUSSION}

From the sections above, the complexity of the nexus between water and other non-water related issues can be observed, be they energy, security, or other developmental aspects. Based on that, four key lessons can be deduced.

First, the regional water security problems are linked to many issues, which are not always water related but rather are associated with the developmental dimension. Although there is often an intuitive connection between water issues and hydropower and agriculture through the water-energy-food/agriculture nexus, that is actually an oversimplification. The problem of inefficient cooperation among States might also be rooted to national security, State-building, social stability and other issues not deeply analysed in this paper. As the focus of this paper was narrowed down to certain elements, only the tip of an iceberg was covered. Future solutions should embrace the complexity of the issue and be based on holistic approaches.

Second, it is important to avoid overly simplified conclusions and solutions. The prevailing mistrust and zero-sum logic are the result of many factors, which may be difficult to track if coverage is limited to only the water sector. In addition, the disintegration processes in the regions seem to continue (Makeev, 2018), which hinder the prospects of meaningful water cooperation.

Third, there needs to be a careful account of how water security problems are triggered and what they trigger. For example, Spoor and Krutov (2003) argue that the competition over water resources in Central Asia may intensify growing irredentist sentiments and partly drive inter-ethnic confrontation. There is lack of direct causality between the two, but when looking at the resource constraints as a threat multiplier, "it is more productive to conceive of conflict as a social process rather than a causal relationship between scarcity and violence" (Bichsel, 2009, p. 125).

Finally, climate change is another complicating factor not covered in this paper, but worth mentioning. In Central Asia and Southern Caucasus, climate change-related risks are somewhat similar - that is, the disruption of water resources and reduction in long-term water reserves. The assessment of the change in water regime in the 
Commonwealth of Independent States, including those in Central Asia and Southern Caucasus, according to climate change scenarios, indicates that water stocks will decline further in areas that already experience scarcity. At the same time, declines in precipitation during summer will threaten food security, while growth of average temperatures will make the habitat less comfortable for living (Blinov, 2012).

The dynamics at which climate change will drive the regional security situation are also diverse and complex. According to the Stockholm International Peace Research Institute, water stress caused by climate change will have severe implications on the lifestyles of people living in the areas dependent on agriculture of arid and semi-arid zones. This can pose a serious threat to the livelihood of marginalized groups and is, therefore, linked to human security issues. The team from the institute suggested that there is a "concern that recent shifts in precipitation - and predicted future shifts - will increase competition over scarce water resources, both within and between states" (Mobjörk and others, 2016, p. 6). The adaptation to and mitigation of the effects of climate change requires bold measures at the country and the interstate level. Already there are problems to develop the necessary solutions because of unresolved disputes. For example, in 2015, during the high-level segment of the twenty-first session of the Conference of the Parties (COP 21) of the United Nations Framework Convention on Climate Change (UNFCCC) $)^{12}$ meeting, an Azerbaijani official stated that the "efficient realization of climate change mitigation and adaptation actions are conditioned by the ability of Azerbaijan to exercise effective control over its territory". ${ }^{13}$

\section{CONCLUSION AND RECOMMENDATIONS}

In this paper, the complexity of water-security nexus in Central Asia and Southern Caucasus and its connection to development of both regions is investigated. The analysis suggests that water security is multidimensional and is linked to many other non-water related issues. Accordingly, it cannot be dealt with in isolation. Building on these interdependencies, the following policy solutions are proposed.

Reaching an agreement that deals with existing tensions in Central Asia related to conflicting modes of hydraulic facilities' operation and new infrastructure building should consider going beyond the traditional approach of linking only water and energy. Instead, the viable strategy should be based on "linking of upstream-downstream issues with issues "beyond" the river that facilitates quid pro quos and side payments" (Ho, 2017, p. 144). To this end, the negotiations need to be broadened to address

12 Conference of the Parties of the United Nations Framework Convention on Climate Change (UNFCCC).

${ }^{13}$ See Statement of the delegation of the Republic of Azerbaijan with regard to the written statement of the Delegation of the Republic of Armenia. Available at https://unfccc.int/files/meetings/paris_ nov_2015/application/pdf/cop21cmp11_hls_speech_azerbaijan_in_reply_to_armenia.pdf. 
existing challenges holistically. Although some suggest that the linkages can be made in relation to financial resources, energy resources, political linkages and data to encourage positive-sum solutions (Wolf, 1997), in Central Asia, it is imperative to consider the domestic level political peculiarities of each State that influences the interstate cooperation patterns, and begin from low-hanging fruits and gradually expanding the cooperation mode to new areas.

At the same time, it is critical to move towards enhanced benefit sharing stemming from cooperation and usage of shared water resources. While benefit sharing should be considered as complementary to issue-linkaging, it must be carried out through a phased approach by moving towards issues of "existential matter" only systematically. This requires refocusing from water's physical volumes to the values coming from water use in the economic, social, political, and environmental spheres. Over time, the benefits "may include reduced effects of hydrologic variability, flood and drought mitigation, increased system-wide yields of water, improved environmental management, and hydropower generation" (Qaddumi, 2008, p. 4).

At the country level, the focus should be on lessening the water-intensity of countries' economies and their exports. Data suggest that Kazakhstan and Turkmenistan are net exporters of both green and blue water, ${ }^{14} \mathrm{Kyrgyzstan}$ is a net importer of both, and Tajikistan and Uzbekistan import green water and export blue water (Stucki and Sojamo, 2012). Consequently, while water allocation from transboundary sources remains critical in ensuring water security, reduction of water intensity may mitigate a number of pressing issues, especially in downstream States and water-scarce basins.

In Southern Caucasus, bringing about peace requires a systemic approach that involves crossing the boundaries of issue areas. Although some scholars suggest that starting the talks from water may be one of the entry points to begin future peace talks, as was the case in Southern African States where water became "one of the foundations for cooperation" or during "picnic table" talks between Israel and Jordan in 1953 on management of the Jordan River amid war between them (Wolf and others, 2006, p. 3), without proper confidence-building measures, this might not extend far. As mentioned earlier, the mere existence of an agreement does not necessarily mean effective cooperation between participating States. The goal in Southern Caucasus should be to find the middle ground among countries in order to lay a foundation for countries to prosper together. The measures should be comprehensive and systemic with water becoming one of the many key elements at the table.

14 According to Malin Falkenmark, an expert on sustainable use of water, there are two types of water - blue and green water. Water from aquifers, lakes, and dams is generally understood to be blue water, and the moisture in soil and plants is referred to as green water. For more information, see Falkenmarkand Rockström (2006). 


\section{REFERENCES}

Allouche, Jeremy (2005). "Water nationalism: an explanation of the past and present conflicts in Central Asia, the Middle East and the Indian subcontinent?". PhD, diss., Graduate Institute of International and Development Studies.

Bekchanov, Maksud, and others (2015). How would the Rogun dam affect water and energy scarcity in Central Asia? Water International, vol. 40, No. 5-6, pp. 856-876.

Bichsel, Christine (2009). Conflict Transformation in Central Asia. Oxford, United Kingdom: Routledge.

Blinov, Yuri (2012). Otsenka Vozdeistviia Izmeneniia Klimata Na Vodnye Resursy Kazahstana. Technical Report. August-December.

Bruntland Commission (1987). Our Common Future: Report of the World Commission on Environment and Development, World Commission on Environment and Development. In Annex to General Assembly Document A/42/427, 4 August 1987.

Central Asian Research Institute for Irrigation (1993). ICWC Bulletin No.2. Interstate Commission for Water Coordination of Central Asia. Tashkent. Available at www.icwc-aral.uz/pdf/02-ru.pdf.

Cook, Christina, and Karen Bakker (2012). Water security: debating an emerging paradigm. Global Environmental Change, vol. 22, No.1, pp. 94-102.

De Waal, Thomas (2005). The Nagorny Karabakh conflict: origins, dynamics and misperceptions. In The Limits of Leadership: Elites and Societies in the Nagorny Karabakh Peace Process, Accord Issue 17, Laurence Broers ed. London: Conciliation Resources.

Delli Priscolli, Jerome, and Aaron Wolf (2009). Managing and Transforming Water Conflicts. Cambridge, United Kingdom: Cambridge University Press.

Dietzen, Mark (2014). Whose hands on the spigot? Water security and the Nagorno Karabakh conflict. Streit Council for a Union of Democracies.

Falkenmark, Malin, and Johan Rockström (2006). The new blue and green water paradigm: breaking new ground for water resources planning and management. Journal of Water Resources Planning and Management, vol. 132, No. 3, pp. 129-132.

Gleick, Peter H. (2006). Water and terrorism. Water Policy, vol. 8, No. 6, pp. 481-503.

Gleick, Peter H., and Matthew Heberger (2014). Water conflict chronology. In The World's Water, Peter H. Gleick and other, eds. Washington, D.C.: Island Press.

Ho, Selina (2017). China's transboundary river policies towards Kazakhstan: issue-linkages and incentives for cooperation. Water International, vol. 42, No. 2, pp. 142-162.

Ibatullin, Sagit (2013). Water resources in Central Asia: current status, problems and perspectives of use. Unpublished Paper.

Intelligence Community Assessment (2012). Global water security, IC-coordinated paper, ICA 2012-08, 2 February 2012. Available at www.dni.gov/files/documents/Special\%20 Report_ICA\%20Global\%20Water\%20Security.pdf.

Ivanova, Nadya (2009). The forgotten South Caucasus: where oil and water mix. Circle of Blue, 3 July. Available at www.circleofblue.org/2009/world/the-forgotten-south-caucasuswhere-oil-and-water-mix/. 
Kistin, Elizabeth, and D. J. H. Phillips (2007). A critique of existing agreements on transboundary waters and proposals for creating effective cooperation between co-riparians. Paper presented at the Third International Workshop on Hydro-hegemony, London School of Economics, London, United Kingdom, May.

Libiszewski, Stephan (1992). What is an Environmental Conflict? Zurich: Center for Security Studies. Available at https://css.ethz.ch/en/services/digital-library/publications/publication.html/236.

Makeev, Talaibek (2018). Interview by author, 24 December.

Micklin, Philip (2000). Managing Water In Central Asia. London: The Royal of International Affairs.

Mirumachi, Naho (2010). "Study of conflict and cooperation in international transboundary river basins: the TWINS Framework", PhD, diss., King's College London.

Mobjörk, Malin, and others (2016). Climate-related Security Risks: Towards an Integrated Approach. Stockholm: Stockholm International Peace Research Institute.

News am (2015). Armenia MFA: PACE report on Sarsang reservoir plays into hands of Azerbaijan propaganda, 24 November. Available at https://news.am/eng/news/297944.html.

Obertreis, Julia (2017). Imperial Desert Dreams: Cotton Growing and Irrigation in Central Asia, 1860-1991, vol. 8. Götingen: Vandenhoeck and Ruprecht.

O'Hara, Sarah (2000). Lessons from the past: water management in Central Asia. Water Policy, vol. 2, No. 4-5, pp. 365-384.

Organization for Security and Co-operation in Europe (2009). Statement by the OSCE Minsk Group Co-Chair countries. L’Aquila, Italy, 10 July. Available at www.osce.org/mg/51152.

Philip, Diana, and others (2015). Water Cooperation Quotient. Mumbai: Strategic Foresight Group. Available at www.strategicforesight.com/publication_pdf/28799WCQ-web.pdf.

Qaddumi, Halla (2008). Practical approaches to transboundary water benefit sharing. Working Paper 292. Results of ODI research presented in preliminary form for discussion and critical comment. London: Overseas Development Institute.

Rucevska, Leva (2017). Climate Change and Security in the South Caucasus, Republic of Armenia, Republic of Azerbaijan and Georgia: Regional Assessment. Organization for Security and Co-operation in Europe. Available at www.osce.org/secretariat/355546?download=true.

Rzayev, R. (2015). The occupied Sarsang water reservoir as a means of hydro-diversion and hydroterror by Armenia against Azerbaijan. In Global and Regional Hydropolitical Problems in the Context of International Cooperation and Security. Collection of speeches and articles, International Conference, 25 November 2014. Baku: Center for Strategic Studies under the President of the Republic of Azerbaijan.

Schmeier, Susanne, and others (2018). Are water and conflict linked and what actually links them? Water, Peace and Security Opinion Piece. Available at www.un-ihe.org/sites/default/ files/opinion_piece_wps_final_0.pdf.

Slim, Hugo (1995). What is development? Development in Practice, vol. 5, No. 2, pp. 143-148.

Smith, David (1995). Environmental security and shared water resources in post-Soviet Central Asia. Post-Soviet Geography, vol. 36, No. 6, pp. 351-370.

Spoor, M, and A. Krutov (2003). The 'power of water' in a divided Central Asia. Perspectives on Global Development and Technology, vol. 2, No. 34, pp. 593-614. 
Stucki, Virpi, and Suvi Sojamo (2012). Nouns and numbers of the water-energy-security nexus in Central Asia. International Journal of Water Resources Development, vol. 28, No. 3 , pp. 399-418.

Ullman, Richard (1983). Redefining security. International Security, vol. 8, No. 1, pp. 129-153.

UN-Water (2013). Water Security and the Global Water Agenda. A UN-Water Analytical Brief. Available at www.unwater.org/publications/water-security-global-water-agenda/.

Warner, Jeroen, and Neda Zawahri (2012). Hegemony and asymmetry: multiple-chessboard games on transboundary rivers. International Environmental Agreements: Politics, Law and Economics, vol. 12, No. 3, pp. 215-229.

Wegerich, Kai (2004). Coping with disintegration of a river-basin management system: multidimensional issues in Central Asia. Water Policy, vol. 6, No. 4, pp. 335-344.

(2008). Hydro-hegemony in the Amu Darya Basin. Water Policy, vol. 10, No. S2, pp. 71-88.

Wegerich, Kai, and others (2015). Water security in the Syr Darya Basin. Water, vol. 7, No. 9, pp. 4657-4684.

Weinthal, Erika (2002). State Making and Environmental Cooperation: Linking Domestic and International Politics in Central Asia. Cambridge, Massachusetts: MIT Press.

Wolf, Aaron (1997). International water conflict resolution: lessons from comparative analysis. International Journal of Water Resources Development, vol. 13, No. 3, pp. 333-66. Available at https://doi.org/10.1080/07900629749728.

(1999). The transboundary freshwater dispute database project. Water International, vol. 24, No. 2, pp. 160-163.

Wolf, Aaron, and others (2006). Water can be a pathway to peace, not war. Navigating Peace, vol. 1, pp. 1-6.

Wolf, Aaron, Shira Yoffe, and Mark Giordano (2003). International waters: indicators for identifyng basins at risk. Technical Documents in Hydrology: PC-CP Series. Availble from http:// unesdoc.unesco.org/images/0013/001333/133306e.pdf.

World Bank (2019). Weather, Climate and Water in Central Asia. A Guide to Hydrometeorological Services in the Region. Available at https://zoinet.org/wp-content/uploads/2018/01/ Hydromet-Atlas-EN-spread.pdf.

Yoffe, Shira, and Kelli Larson (2001). Basins at Risk: Water Event Database Methodology. Available at https://transboundarywaters.science.oregonstate.edu/content/basins-risk.

Zeitoun, Mark, and Naho Mirumachi (2008). Transboundary water interaction I: reconsidering conflict and cooperation. International Environmental Agreements: Politics, Law and Economics, vol. 8, No. 4, pp. 297-316.

Zeitoun, Mark, Naho Mirumachi, and Jeroen Warner (2011). Transboundary water interaction II: the influence of 'soft' power. International Environmental Agreements: Politics, Law and Economics, vol. 11, No. 2, pp. 159-178. 